\title{
Carbon Footprint Analyses of Wastewater Treatment Systems in Puducherry
}

\author{
G. Vijayan ${ }^{1 *}$, R. Saravanane ${ }^{2}$, T. Sundararajan ${ }^{2}$ \\ ${ }^{1}$ Public Works Department, Puducherry, India \\ ${ }^{2}$ Department of Civil Engineering, Pondicherry Engineering College, Puducherry, India \\ Email: *er.gvijayan@gmail.com
}

How to cite this paper: Vijayan, G., Saravanane, R. and Sundararajan, T. (2017) Carbon Footprint Analyses of Wastewater Treatment Systems in Puducherry. Computational Water, Energy, and Environmental Engineering, 6, 281-303. https://doi.org/10.4236/cweee.2017.63019

Received: April 21, 2017

Accepted: July 24, 2017

Published: July 27, 2017

Copyright (๑) 2017 by authors and Scientific Research Publishing Inc. This work is licensed under the Creative Commons Attribution International License (CC BY 4.0).

http://creativecommons.org/licenses/by/4.0/

\section{c) (†) Open Access}

\begin{abstract}
Carbon footprint analysis is a method to quantify the life cycle Greenhouse Gases (GHGs) emissions and identify the measure to reduce climate change impacts. The Intergovernmental Panel on Climate Change (IPCC) has identified that the global warming and climate change which is one of the most important issues in the domain of environment are caused by the excessive emission of Greenhouse Gases (GHG) mainly constituting Carbon dioxide $\left(\mathrm{CO}_{2}\right)$, Methane $\left(\mathrm{CH}_{4}\right)$ and Nitrous oxide $\left(\mathrm{N}_{2} \mathrm{O}\right)$. The municipal wastewater treatment plant receives wastewater for treatment and finally discharges the treated effluent. The emissions of GHG during the treatment of wastewater as well as during the treatment process of sludge and also for energy generation are known to be on-site GHG emissions. Off-site GHG emissions are generated due to transportation and disposal of sludge, off-site energy and chemical production. In Puducherry, the municipal wastewater is being treated using oxidation ponds, Upflow Anaerobic Sludge Blanket (UASB) and Sequencing Batch Reactor (SBR). Wastewater treatment using Sequencing Batch Reactor (SBR) technology is one of the state-of-the art wastewater management systems. In this technology equalization, biological treatment and secondary clarification are performed in a single reactor in a time control sequence. The emissions of GHG from the Oxidation ponds of $12.5 \mathrm{MLD}$, UASB reactor of 2.5 MLD and SBR of 17 MLD were assessed based on the IPCC guidelines and the total emissions of GHG in terms of equivalent of $\mathrm{CO}_{2}$ were compared. The performance of the SBR is more efficient and the emissions of GHG are less than the emissions in the UASB as well as in oxidation ponds. The emission of GHG in SBR is about $60 \%$ of the existing treatment systems of oxidation ponds and UASB thus a reduction of $40 \%$ GHG emission could be achieved.
\end{abstract}

\section{Keywords}

Greenhouse Gas (GHG), Intergovernmental Panel on Climate Change (IPCC), Global Warming Potential (GWP), Sequencing Batch Reactor (SBR), Upflow Anaerobic Sludge Blanket (UASB) 


\section{Introduction}

\subsection{Definition of Carbon Footprint}

Carbon footprint is defined as the total set of greenhouse gas emissions caused by an activity or product expressed as carbon dioxide equivalent. It is a measure of the total amount of carbon dioxide $\left(\mathrm{CO}_{2}\right)$, methane $\left(\mathrm{CH}_{4}\right)$ and Nitrous Oxide $\left(\mathrm{N}_{2} \mathrm{O}\right)$ emissions of a defined system or activity, considering all relevant sources and sinks within the system or activity. It is calculated as carbon dioxide equivalent using the relevant 100-year global warming potential (GWP100). The main constituents of the GHG are carbon dioxide $\left(\mathrm{CO}_{2}\right)$, methane $\left(\mathrm{CH}_{4}\right)$ and nitrous oxide $\left(\mathrm{N}_{2} \mathrm{O}\right)$. The accounted GHG emissions are indexed in terms of global warming potential (GWP) by converting in terms of $\mathrm{CO}_{2}$ with a base value over a period of 100 years namely, 1 for $\mathrm{CO}_{2}, 21$ for $\mathrm{CH}_{4}$ and 310 for $\mathrm{N}_{2} \mathrm{O}$ [1] [2]. Even though $\mathrm{CO}_{2}$ emissions from biological wastewater treatment are not normally considered, some studies have pointed out that about $20 \%$ of the carbon present in the wastewaters can be of fossil origin and the emissions of fossil $\mathrm{CO}_{2}$ from wastewater treatment were underestimated. The sources of GHG may be either natural or anthropogenic. Further the identification and quantification of all sources are essential for developing the strategy to control and reduce the rate of increase of the emissions of GHG. The wastewater treatment plants (WWTP) are considered as source of GHG emissions because of the generation of $\mathrm{CO}_{2}$, $\mathrm{CH}_{4}$ and $\mathrm{N}_{2} \mathrm{O}$ during the process of treatment and energy demand.

In a defined system boundary, the emissions of GHG from different scenarios can be estimated and evaluated. The GHG emissions include 1) direct emission of GHG from wastewater treatment comprising emission of $\mathrm{CO}_{2}$ due to degradation of organic matters, emission of $\mathrm{N}_{2} \mathrm{O}$ during the process of nitrification and denitrification and emissions of $\mathrm{CH} 4$ and $\mathrm{N}_{2} \mathrm{O}$ from anaerobic digestion during sludge treatment and 2) indirect emissions of GHG from sludge treatment, usage of electrical power and chemicals during the operation and maintenance of the treatment plant and disposal of sludge. Apart from these, the production and transportation of construction materials also cause indirect emissions of GHG [3].

\subsection{Carbon Credit Scheme in Wastewater Treatment}

Global warming and climatic change is being viewed as an international problem and several studies establish the significance of Greenhouse Gas (GHG) emissions from the wastewater process and the impact on the ecosystem. Wastewater treatment plants (WWTPs) are some of the sources of GHG emission. The wastewater treatment processes use biological and physio-chemical processes for the removal of contaminants and produce the three primary GHGs, i.e. carbon dioxide $\left(\mathrm{CO}_{2}\right)$, methane $\left(\mathrm{CH}_{4}\right)$ and nitrous oxide $\left(\mathrm{N}_{2} \mathrm{O}\right)$ during the treatment operation and energy generation processes.

Aerobic treatment systems produce primarily $\mathrm{CO}_{2}$, whereas anaerobic systems produce a mixture of $\mathrm{CH}_{4}$ and $\mathrm{CO}_{2}$. When the sludge generated from the wastewater treatment unit is digested on-site, then, there will be additional $\mathrm{CO}_{2}$ and $\mathrm{CH}_{4}$ 
emissions. $\mathrm{N}_{2} \mathrm{O}$ is produced during the processes denitrification, nitrification and during chemical reactions that take place in the WWTP. There is considerable interest to determine carbon footprints of Wastewater Treatment Plants (WWTPs) with respect to Greenhouse Gas (GHG) emissions, energy usage, energy production, and carbon credits.

The Global Warming Potential (GWP) of a GHG is the ratio of heat trapped by one unit mass of the gas compared to one unit mass of $\mathrm{CO}_{2}$ over a specified time period (typically 100 years). The GWP of $\mathrm{N}_{2} \mathrm{O}$ is $310 \mathrm{~kg}$ equivalent $\mathrm{CO}_{2}$ and for $\mathrm{CH}_{4}$ it is 21. To model the GHGs of a WWTP it is therefore important to take the $\mathrm{N}_{2} \mathrm{O}$ emissions into account. The GWP varies significantly, depending on the type of GHG. Therefore, a small quantity of GHG emitted with a high GWP has a greater effect on the atmosphere than a GHG with low GWP.

\subsection{The Global Greenhouse Gas Emissions}

The IPPC has developed the concept of Global warming potential (GWP) for comparing the ability of each of the GHG to trap heat in the atmosphere relative to another gas. The GWP of a GHG is the ratio of heat trapped by one unit mass of the gas compared to one unit of $\mathrm{CO}_{2}$ over a time period of 100 years [4]. The key greenhouse gases emitted due to anthropogenic activities are $\mathrm{CO}_{2}, \mathrm{CH}_{4}$ and $\mathrm{N}_{2} \mathrm{O}$. As per IPCC (2014) based on global emissions from 2010, out of the total global GHG emissions, $\mathrm{CO}_{2}$ alone constitutes about $76 \%$ from fossil fuel, industries, forestry and land use. The $\mathrm{CH}_{4}$ constitute about $16 \%, \mathrm{~N}_{2} \mathrm{O}$ constitute $6 \%$ and F-gases constitute about $2 \%$ as shown in Figure 1.

The global greenhouse gas emissions by economic sector various sectors as per IPCC 2014 based on global emissions from 2010 are indicated in Figure 2. Out of the total GHG emissions, $25 \%$ is from Electricity \& heat production, $24 \%$ is from agriculture, forestry $\&$ other land use, $6 \%$ from buildings, $14 \%$ is from transportation, $21 \%$ from industrial process and $10 \%$ from other energy. Generally, the $\mathrm{CO}_{2}$ emission from biological wastewater treatment is not considered while accounting the GHG emissions since it is biogenic origin. Out of the total emissions of $\mathrm{CH}_{4}$ and $\mathrm{N}_{2} \mathrm{O}$ from various sources about $18.1 \%$ is from waste disposal

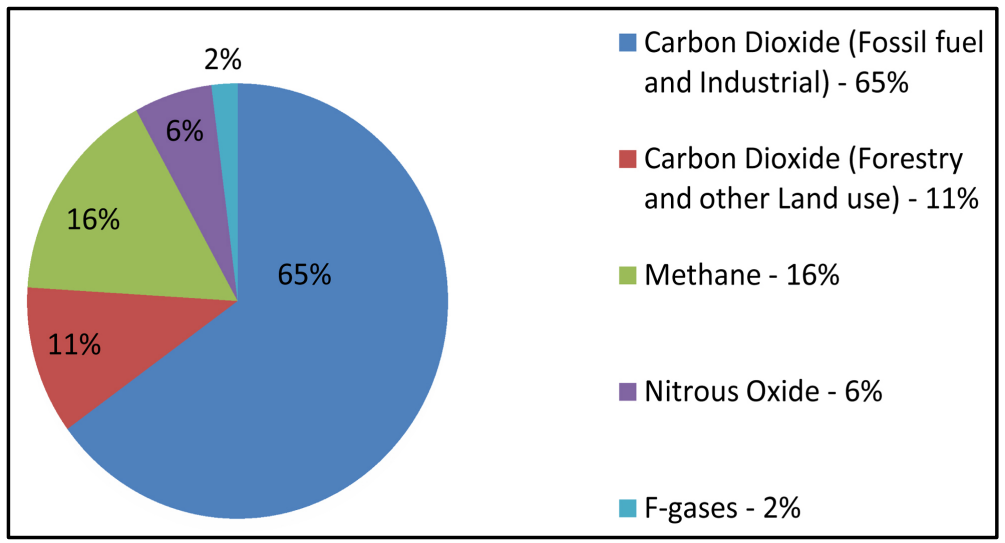

Figure 1. Global greenhouse gas emissions by gas.

Source: IPCC (2014) based on global emissions from 2010. 


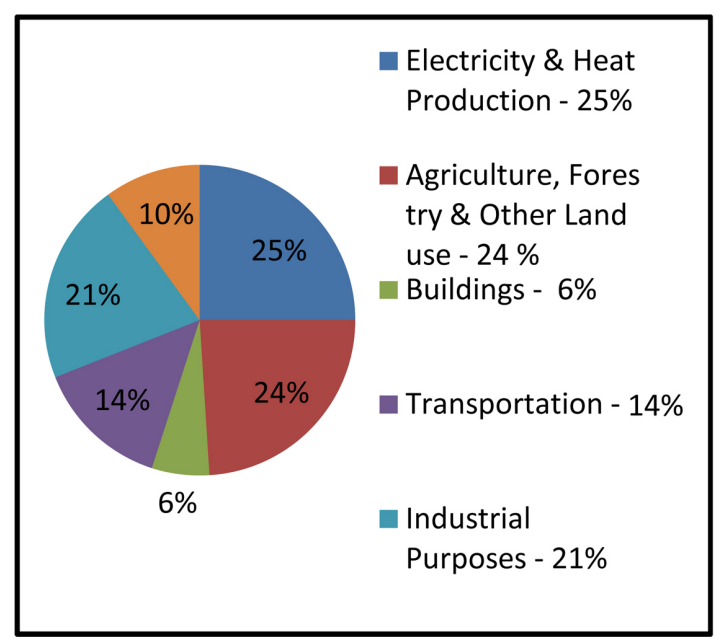

Figure 2. Global GHG emissions by economic sector.

and treatment. Similarly, out of the total emissions of $\mathrm{N}_{2} \mathrm{O}, 2.3 \%$ is from waste disposal and treatment.

\subsection{Trends in Global $\mathrm{CO}_{2}$ Emissions: 2014 Report}

Among the six largest $\mathrm{CO}_{2}$ emitting countries, remarkable trends were reported in the top $3 \mathrm{CO}_{2}$ emitting countries, which account for $55 \%$ of total global $\mathrm{CO}_{2}$ emissions in 2011 [5]. China is the largest $\mathrm{CO}_{2}$ emitting country, sharing about $28 \%$ of the total emissions of $\mathrm{CO}_{2}$ in 2011 which was much larger than the second-largest, the United States, with $16 \%$, the European Union with $10 \%$, India with 6\%, The Russian Federation with $6 \%$ and Japan with $4 \%$ as shown in Figure 3. India is the fourth largest $\mathrm{CO}_{2}$ emissions country in 2011 with a $\mathrm{CO}_{2}$ emission of about 2.1 billion tonnes. The increase in emission level is partly because of increase in population and economy. The per capita $\mathrm{CO}_{2}$ emission of India is 1.7 tonnes of $\mathrm{CO}_{2}$, which is much lower than those of most developed countries and China. The output of domestic wastewater in urban areas is influenced by multiple factors. The gross domestic product (GDP) is an important comprehensive indicator reflecting the economic development of a country. Economic development and improvement of people's living conditions promote an increase in domestic wastewater and COD discharge and removal. A study on the characteristic data and GDP data on domestic wastewater treatment showed that the quantity of domestic wastewater effluent grows annually with a stable GDP growth. The statistical calculation model for the quantity of domestic wastewater effluent showed a linear relationsahip with GDP. The relevant data of GDP and the characteristics of wastewater can be used to analyze the relationship between GDP and domestic wastewater discharge, and COD discharge and removal. The trends in share of national GDP and the $\mathrm{CO}_{2}$ emissions are shown in Table 1.

\subsection{Greenhouse Gas Emissions in India}

Internationally, the Indian Government has voluntarily agreed to reduce the 


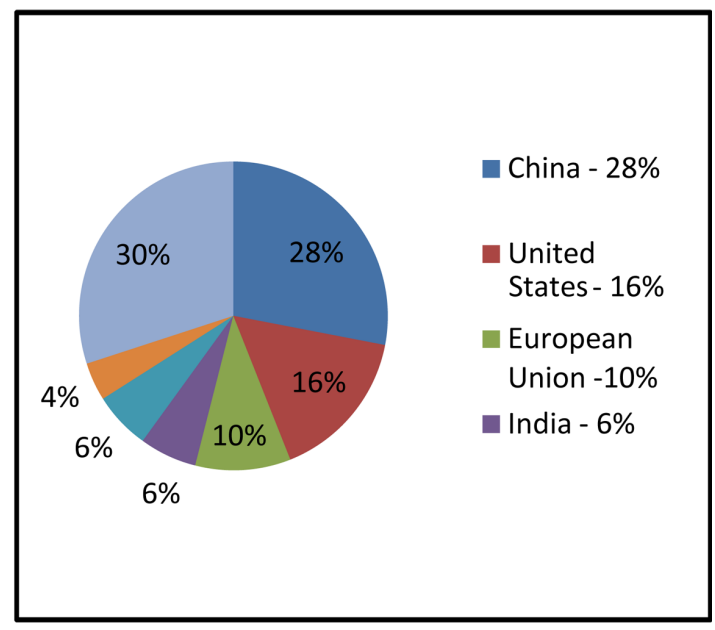

Figure 3. National $\mathrm{CO}_{2}$ emissions. Source: IPCC (2014) based on global emissions from 2010 and 2011.

Table 1. Trends in national GDP (\%) and $\mathrm{CO}_{2}$ emissions in during 2013.

\begin{tabular}{ccccc}
\hline Country & $\begin{array}{c}\text { Shares of national } \\
\text { GDP (\%) on PPP } \\
\text { basis }\end{array}$ & $\begin{array}{c}\% \mathrm{CO}_{2} \text { global } \\
\text { emission }\end{array}$ & $\begin{array}{c}\mathrm{CO}_{2} \text { emission in } \\
\text { billion tonnes }\end{array}$ & $\begin{array}{c}\text { Per capita } \mathrm{CO}_{2} \\
\text { emissions in } \\
\text { tonnes }\end{array}$ \\
\hline China & 15 & 29 & 10.3 & 7.40 \\
USA & 16 & 15 & 5.3 & 16.6 \\
EU28 & 17 & 11 & 3.70 & 7.3 \\
India & 7 & 6 & 4.30 & 1.7 \\
Russia & 3 & 5 & 1.80 & 12.6 \\
Japan & 3 & 4 & 1.40 & 10.7 \\
\hline
\end{tabular}

Source: Trends in global $\mathrm{CO}_{2}$ emissions: 2014, PBL Netherlands Environmental Assessment Agency.

emissions intensity of its gross domestic product (GDP) by 20 - 25 percent from 2005 levels by 2020. Indian and international studies suggest that India is likely to meet or even exceed this pledge based on its existing policy package and macroeconomic trends. Nevertheless, significant uncertainty surrounds the effective implementation of these policies and changes in the GDP composition [6].

The emissions of GHG from wastewater are from domestic and disposal from the industries. The total $\mathrm{CO}_{2}$ equivalent emissions from waste water generating sources in India in 2007 was 45 million tons, which is $82 \%$ of the total $\mathrm{CO}_{2}$ equivalent emissions from the waste sector [7]. The total methane emitted in 2007 was 1.9 million tons and $\mathrm{N}_{2} \mathrm{O}$ emitted was 15.8 thousand tons as shown in Table 2.

In India, domestic wastewater has been categorized as urban high, urban low \& rural, since the characteristics of the municipal wastewater vary from place to place depending on several factors such as economic status, food habits of the community, water supply status and climatic conditions of the area. In India, the wastewater treatment is provided only in Class I and II cities. Sewage contributes to $60 \%$ of the total pollution load in terms of biological oxygen demand which is beneficial if recovered through the anaerobic treatment process. 
Table 2. GHG emission from waste water sector in India (Thousand tonnes).

\begin{tabular}{cccc}
\hline Activity & $\mathrm{CH}_{4}$ & $\mathrm{~N}_{2} \mathrm{O}$ & $\mathrm{CO}_{2}$ equivalent \\
\hline Domestic & 861 & 15.8 & 22,979 \\
Industrial & 1050 & - & 22,050 \\
Total & 1911 & 15.8 & 45,029 \\
\hline
\end{tabular}

\subsection{The GWP Values for the GHG}

Determination of carbon footprints of Wastewater Treatment Plants (WWTPs) with respect to greenhouse gas emissions, energy usage, energy production, and carbon credits are gaining interest. For the estimation of GHG emissions in a WWTP, the inventory of all GHGs emitted has to be considered and the appropriate global warming potential (GWP) for each gas has to be determined. The Global Warming Potential (GWP) of a GHG is the ratio of heat trapped by one unit mass of the gas compared to one unit mass of $\mathrm{CO}_{2}$ over a specified time period (typically 100 years). The GWP varies significantly based on the type of constituent GHG. A small quantity of gas emitted with a high GWP will have the same heat trapping potential as that of large quantity of gas emitted with low GWP [8].

The GWP varies significantly, depending on the type of gas. Therefore, a small quantity of gas emitted with a high GWP has a greater effect on the atmosphere than a gas with low GWP. For example one kilogram $(\mathrm{kg})$ of $\mathrm{N}_{2} \mathrm{O}$ emitted will have the same heat trapping potential as $310 \mathrm{~kg}$ of $\mathrm{CO}_{2}$. The Global Warming Potential of GHGs produced in WWTPs as per IPCC, 2001, Research Triangle Institute, 2010 (USEPA) are shown in Table 3.

The emissions of GHG in WWTPs are associated with both on-site and off-site sources. The on-site sources of GHG emission include liquid and solid treatment processes as well as the combustion of fuels and biogas for energy generation. The off-site sources include the production and transmission of electricity, fuel and chemicals for off-site use, as well as solid waste transportation and disposal such as landfill, composting and degradation of remaining constituents in liquid effluent. The GHG emission by on-site and off-site processes in aerobic, anaerobic and hybrid system of biological wastewater treatment plants is shown in Figure 4.

Table 3. Global warming potential (GWP) of the GHGs.

\begin{tabular}{ccccc}
\hline \multirow{2}{*}{ GHGs } & $\begin{array}{c}\text { Chemical } \\
\text { formula }\end{array}$ & $\begin{array}{c}\text { Lifetime in } \\
\text { years }\end{array}$ & \multicolumn{2}{c}{$\begin{array}{c}\text { Global warming potential for } \\
\text { given time horizon (100 years) }\end{array}$} \\
\cline { 4 - 5 } Carbon dioxide & $\mathrm{CO}_{2}$ & 100 & 1 & RTI (USEPA) 2010 \\
Methane & $\mathrm{CH}_{4}$ & 12 & 23 & 21 \\
Nitrous oxide & $\mathrm{N}_{2} \mathrm{O}$ & 114 & 296 & 310 \\
\hline
\end{tabular}

Source: RTI (USEPA)-Research Triangle Institutes International, United States Environmental Protection Agency. 


\subsection{Objective of the Study}

The objective of this study is to examine the emission of the greenhouse gases and the global warming potential due to the treatment of wastewater in Puducherry, India and to assess the possible reduction potential of GHG emissions to obtain carbon credit.

\section{Study Area and Present Scenario}

Puducherry, the erstwhile French Colony is a coastal city, located at $11^{\circ} 58^{\prime} 12^{\prime \prime} \mathrm{N}$, $79^{\circ} 48^{\prime} 40^{\prime \prime} \mathrm{E}$ and it is located at $162 \mathrm{~km}$ south of Chennai, India. The urban population of Puducherry as per 2011 census is 6.54 lakhs. Puducherry town has been provided with underground sewerage facilities partially as early as 1980 and the municipal wastewater has been treated with an oxidation pond of 2.9 MLD capacity at Karuvadikuppam, in the north western part of the Puducherry. Later on, three more oxidation ponds with treatment capacities of 2.9, 2.2, 4.8 MLD and two Upflow Anaerobic Sludge Blanket (UASB) reactors each having a capacity of 2.5 MLD were added. The installed capacity of all the existing STPs is 17.8 MLD. The BOD removal efficiency of the oxidation ponds and UASBs are about $60 \%$ only. Rapid urbanization and limitation of available space have necessitated adopting modern treatment methods. Accordingly, three Sequencing Batch Reactors (SBRs), each having a capacity of 17 MLD have been provided at

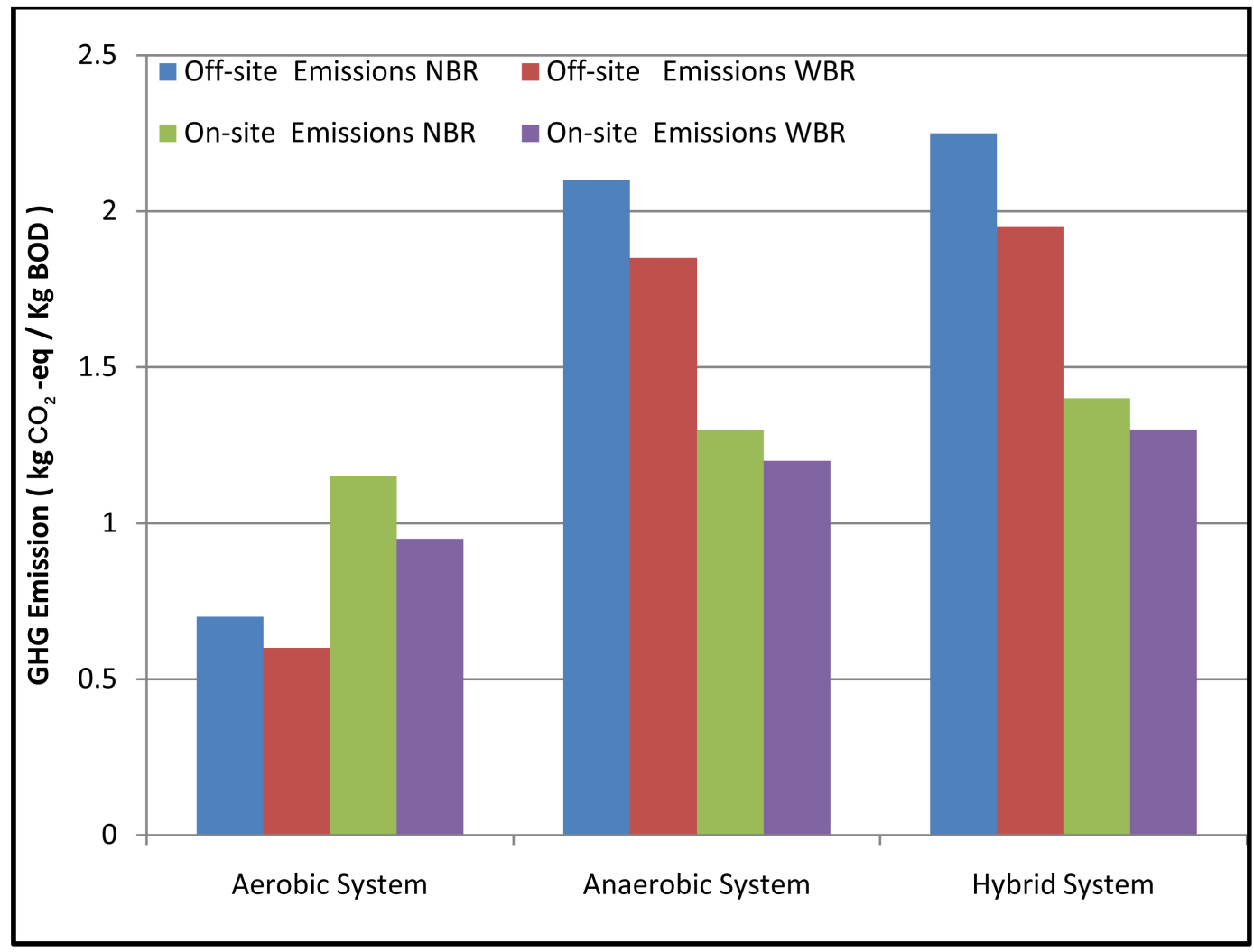

Figure 4. GHG emission by on-site and off-site processes in the biological wastewater treatment plants (NBR = no biogas recovery, $\mathrm{WBR}=$ with biogas recovery).

Source: Water Science \& Technology 2013, 67.5, p. 1163. 
Karuvadikuppam, Dubrayapet and Kanakaneri. All these sewage treatment plants are small scale WWTPs with low carbon footprint. The sludge treatment and disposal not only concern environmental pollution problems, but also play a critical role in reducing the carbon footprint of the whole process. In other words, the energy content in organic matters in the wastewater is either converted to $\mathrm{CO}_{2}\left(\right.$ or $\left.\mathrm{CH}_{4}\right)$ or wasted as sludge through the biological process. The sludge from all these processes are treated by aerobic composting in sludge drying yard and the digested sludge are used for land application. The location of the study area and the STP sites is shown in Figure 5.

\section{Methodology}

\subsection{GHG Emissions}

Both aerobic and anaerobic wastewater treatment processes remove $\mathrm{BOD}_{5}$ and the bacteria in both processes also generate $\mathrm{CO}_{2}, \mathrm{CH}_{4}$ and $\mathrm{N}_{2} \mathrm{O}$ [9]. The methodology used to estimate GHG emissions is based on the Intergovernmental Panel on Climate Change (IPCC, 1996) Revised Guidelines for National Greenhouse Gases Inventory and the IPCC Good Practice Guidance and Uncertainty Management in National Greenhouse Gas Inventories.

Aerobic:

$$
\mathrm{BOD}_{5}+\mathrm{O}_{2}+\text { Nutrients } \rightarrow \mathrm{CO}_{2}+\mathrm{H}_{2} \mathrm{O}+\text { Biosolids }
$$

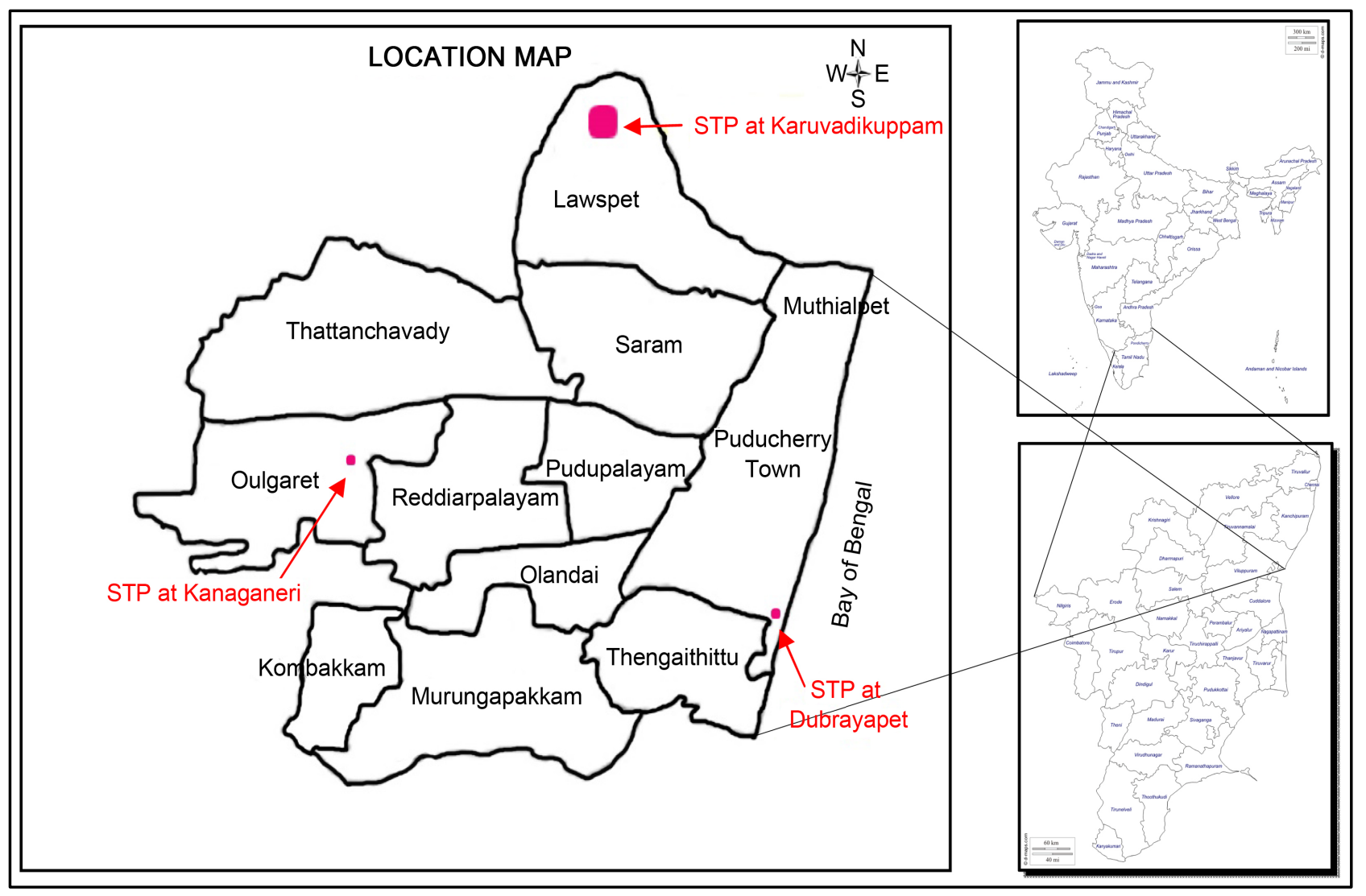

Figure 5. Location map of the study area. 
The anaerobic process is actually performed by heterotrophic bacteria in a 2-step process as follows:

$$
\begin{gathered}
\mathrm{BOD}_{5}+\text { Nutrients } \rightarrow \text { VFA's }+\mathrm{CO}_{2} \text { Acid-Forming Bacteria } \\
\text { VFA's + Nutrients } \rightarrow \mathrm{CO}_{2}+\mathrm{CH}_{4} \text { Methane Bacteria }
\end{gathered}
$$

During aerobic treatment, ammonia $\left(\mathrm{NH}_{4}^{+}\right)$or organic nitrogen is biologically oxidized to nitrites $\left(\mathrm{NO}_{2}^{-}\right)$and nitrates $\left(\mathrm{NO}_{3}^{-}\right)$by autotrophic bacteria through a process called nitrification. $\mathrm{NO}_{2}^{-}$and $\mathrm{NO}_{3}^{-}$can then be converted to nitrogen gas $\left(\mathrm{N}_{2}\right)$ under anoxic conditions (i.e., where dissolved oxygen is absent) by heterotrophic bacteria through a process called denitrification. $\mathrm{N}_{2} \mathrm{O}$ is a by-product of the nitrification process and an intermediate product of the denitrification process.

Nitrification: $\mathrm{NH}_{4}^{+} \rightarrow \mathrm{NH}_{2} \mathrm{OH} \rightarrow \mathrm{NO}_{2}^{-} \rightarrow \mathrm{NO}_{3}^{-}$

Denitrification: $\mathrm{NO}_{3}^{-} \rightarrow \mathrm{NO}_{2}^{-} \rightarrow \mathrm{NO} \rightarrow \mathrm{N}_{2}$

\subsubsection{Aerobic Treatment}

The aerobic treatment is the process in which the complex organic matter present in the wastewater is synthesized by the aerobic bacteria and converted into $\mathrm{CO}_{2}$. In aerobic treatment aeration is carried out either by diffused or submerged aerators in order to maintain adequate quantity of microorganism to oxidize the organic matters. Equalization, biochemical reactions and flocculation take place during aeration. The mixed liquor suspended solids shall be controlled to have sufficient concentration of aerobic bacteria or biomass. The aerated and well mixed liquor is subjected for sedimentation in the settling tank or clarifier. The excess sludge is removed from the setting tank. The activated sludge process is one of the most commonly used biological wastewater treatment system for treatment of both municipal and industrial wastewater. Sequencing batch Reactor system is known to be the pioneer of all activated sludge system and the SBR system operates in time rather than in space [10]-[15].

\subsubsection{Anaerobic Treatment}

The organic matters are metabolized by methanogenic bacteria and synthesized in to new biomass or converted to $\mathrm{CO}_{2}$ or $\mathrm{CH}_{4}$ under anaerobic environment. Even though the growth of anaerobic bacteria is slower than the aerobic bacteria, the degradation of certain types of wastes by the anaerobic bacteria is more rapid than by the aerobic bacteria. During anaerobic digestion the acid- and $\mathrm{CH}_{4}$ forming (methanogenic) bacteria convert organic matter into a biogas consisting of approximately $60 \%-70 \% \mathrm{CH}_{4}, 30 \%-40 \% \mathrm{CO}_{2}$, and trace amounts of $\mathrm{N}_{2}$, hydrogen $\left(\mathrm{H}_{2}\right)$, hydrogen sulphide $\left(\mathrm{H}_{2} \mathrm{~S}\right)$, and $\mathrm{O}_{2}$ [2]. The Upflow Anaerobic Sludge Blanket (UASB) is one of the efficient anaerobic treatment processes for treating both domestic and industrial wastewater.

Anaerobic wastewater treatment system is a more advantageous than the aerobic processes because of its low energy consumption and sludge production [16]. When methane is used as an energy source, GHGs emissions in anaerobic treatment are lower than that of the aerobic technologies and this process has 
the advantages of energy saving, biogas recovery and lower sludge production. Earlier it was viewed that anaerobic process was suitable for high-strength, high temperature wastewaters only, and that it required rigorous $\mathrm{pH}$ control and protection from toxic shocks. But recent researches have shown that anaerobic processes could also be applied to low strength wastewaters at low temperatures successfully.

\subsubsection{Oxidation Ponds}

Oxidation ponds or lagoons may be aerobic (shallow), anaerobic (deep) or facultative (medium depth) depending on the depth of the lagoons. In facultative lagoons aerobic condition will prevail due to aeration by the wind action and at the bottom of the lagoon anaerobic condition will prevail. Within the lagoon the generation of biomass occurs and accumulates at the bottom of the lagoon which is always in anaerobic condition. The $\mathrm{CH}_{4}$ is generated at the bottom of the lagoon and it travels upwards through the aerobic zone near the surface it is oxidized. The oxidation ponds are of different categories namely, aerobic, facultative and anaerobic ponds. In Puducherry there are four oxidation ponds having an area of 52,392 Sqm and an average depth of $1.2 \mathrm{~m}$ and the capacity of all the 4 oxidation ponds is $12.5 \mathrm{Mld}$. The average BOD removal efficiency in the oxidation ponds is from $50 \%$ to $60 \%$. The emission of Greenhouse gases from the Oxidation ponds include $\mathrm{CO}_{2}$ and $\mathrm{CH}_{4}$ as the top surface of the oxidation pond is in aerobic zone and the bottom of the pond is in anaerobic zone. The stabilization ponds typically emit $85 \mathrm{~g} / \mathrm{m}^{2}$ day of $\mathrm{CO}_{2}$ and $86 \mathrm{~g} / \mathrm{m}^{2}$ day of $\mathrm{CH}_{4}$, with nitrous oxide levels significantly lower [17] [18].

\subsubsection{Upflow Anaerobic Sludge Blanket (UASB)}

In an UASB reactor approximately $60 \%-65 \%$ of the influent COD is converted to $\mathrm{CH}_{4}$, depending on the temperature and the characteristics of the sewage. The advantages of conversion of $\mathrm{COD}$ to $\mathrm{CH}_{4}$ are the reduction of the oxygen demand in the aerobic post-treatment unit and the $\mathrm{CH}_{4}$ can be utilized for the generation of heat and electricity. Though the UASB reactor has the advantage of having energy self-sufficient sewage treatment plant (STP) about (20\%-40\%) of the $\mathrm{CH}_{4}$ produced in UASB reactors remains dissolved in the effluent. In most of the USABs the $\mathrm{CH}_{4}$ is emitted into the atmosphere instead of recovery and this leads to the reduction of the potential energy generation from the utilization of the produced biogas and emission of potent greenhouse gas (GHG) in to atmosphere [19]. The uncontrolled greenhouse gas emissions shall be avoided and non-flaring of captured $\mathrm{CH}_{4}$ shall be prohibited. If instead, all the energy is used, with the increasing energy prices and tradable $\mathrm{CO}_{2}$ credits, anaerobic sewage treatment will become an affordable investment for many developing countries.

\subsubsection{Sequencing Batch Reactor (SBR)}

The sequencing batch reactor technology is one of the most commonly used biological wastewater treatment processes at both municipal and industrial wastewater treatment plants. Even though there are many variations of activated sludge biological wastewater treatment processes, all the reactions take place in 
the same reactor and the reactor serves as aeration and sedimentation tank [20]. In SBR, primary sedimentation, biodegradation and biomass separation take place within a single reactor. SBR is a time-oriented technology instead of space-oriented, which can be operated with great flexibility. Ease operation of SBR could be realized by controlling bacterial species which cause filamentous bulking, remove nutrient or hazardous organics.

\subsubsection{Greenhouse Gases (GHG)}

Carbon dioxide $\left(\mathrm{CO}_{2}\right)$ : The main source of $\mathrm{CO}_{2}$ in wastewater is from treatment process and electricity consumption. During aerobic process in activated sludge process, the emission of $\mathrm{CO}_{2}$ is from the breakdown of organic matter in the aeration tank. During anaerobic process the organic matter is converted in to biomass and again in to $\mathrm{CO}_{2}$ and $\mathrm{CH}_{4}$ through endogenous respiration. The other source of $\mathrm{CO}_{2}$ is from sludge digestion and combustion of digester combustion gas [21].

Methane $\left(\mathrm{CH}_{4}\right)$ : The main source of $\mathrm{CH}_{4}$ is during the anaerobic treatment of wastewater as well as from its sludge. The extent of emission of $\mathrm{CH}_{4}$ depends on the quantity of degradable organic material in the wastewater, the temperature, and the type of treatment system. The rate of $\mathrm{CH}_{4}$ emission increases with the increase in temperature. When the temperature is below $15^{\circ} \mathrm{C}$ the methanogens are not active and there is almost no production of $\mathrm{CH}_{4}$.

The Total $\mathrm{CH}_{4}$ emissions from domestic wastewater can be calculated as follows:

$$
\mathrm{CH}_{4} \text { Emission }=\left(\mathrm{BOD}_{\mathrm{i}} \times \mathrm{EF}\right)-\mathrm{R}
$$

where,

$\mathrm{BOD}_{\mathrm{i}}$ is the total organic content in domestic wastewater in the calculation year (TPY);

$\mathrm{EF}$ is the emission factor $\left(\mathrm{kg} \mathrm{CH} \mathrm{CH}_{4}(\mathrm{~kg} \mathrm{BOD})\right)$;

$\mathrm{R}$ is the amount of recycled $\mathrm{CH}_{4}$ in the calculation year $\left(\mathrm{CH}_{4}\right)$.

$$
\mathrm{EF}=\mathrm{Bo} \times \mathrm{M}
$$

where,

Bo, is the maximum $\mathrm{CH}_{4}$ generation capacity.

$\mathrm{M}$ is the $\mathrm{CH}_{4}$ correction for domestic wastewater.

Nitrous Oxide $\left(\mathrm{N}_{2} \mathrm{O}\right)$ : The main source of $\mathrm{N}_{2} \mathrm{O}$ is from the degradation of nitrogen components in the wastewater. Direct emissions of $\mathrm{N}_{2} \mathrm{O}$ may be generated during both nitrification and denitrification process. Nitrification is an aerobic process during which the ammonia and other nitrogen compounds are converted into nitrates $\left(\mathrm{NO}_{3}\right)$ and. Denitrification is the process which occurs under anoxic conditions in which the nitrate is converted in to nitrites $\mathrm{NO}_{2}$ and again in to nitrogen gas $\mathrm{N}_{2}$. Both processes can occur in the plant and in the water body that is receiving the effluent [21].

\subsection{Estimation of GHG Emissions from Wastewater and Sludge Treatment Units}

The Research Triangle Institute International (RTI) has submitted a report to 
the U.S. Environmental Protection Agency, in which the method of estimating $\mathrm{CO}_{2}, \mathrm{CH}_{4}$ and $\mathrm{N}_{2} \mathrm{O}$ emissions from biological wastewater treatment systems based on IPCC has been recommended. The equations provide a general means of estimating the $\mathrm{CO}_{2}$ and $\mathrm{CH}_{4}$ emissions directly from any type of wastewater treatment process assuming all organic carbon removed from the wastewater is converted to either $\mathrm{CO}_{2}, \mathrm{CH}_{4}$ or new biomass. There are different methods to quantify the life cycle greenhouse gases emissions. However the method adopted in this study is as per report of RTI International, submitted to the USEPA based on IPCC.

\subsubsection{Estimation of $\mathrm{CH}_{4}$ and $\mathrm{CO}_{2}$ Emissions from Wastewater}

In wastewater treatment process all organic carbon removed from the wastewater is converted to $\mathrm{CO}_{2}, \mathrm{CH}_{4}$, or new biomass. Aerobic wastewater treatment systems produce primarily $\mathrm{CO}_{2}$ during the process of wastewater treatment, whereas in anaerobic systems a mixture of $\mathrm{CH}_{4}$ and $\mathrm{CO}_{2}$ is produced. The estimation of direct emission of $\mathrm{CO}_{2}$ and $\mathrm{CH}_{4}$ can be done by the following equations [2].

$$
\begin{aligned}
& \mathrm{CO}_{2}=10^{-6} \times \mathrm{Qww} \times \mathrm{OD} \times \mathrm{Eff}_{\mathrm{OD}} \times \mathrm{CF}_{\mathrm{CO}_{2}} \times\left[\left(1-\mathrm{MCF}_{\mathrm{ww}} \times \mathrm{BG}_{\mathrm{CH}_{4}}\right)(1-\lambda)\right] \\
& \mathrm{CH}_{4}=10^{-6} \times \mathrm{Qww} \times \mathrm{OD} \times \mathrm{Eff}_{\mathrm{OD}} \times \mathrm{CF}_{\mathrm{CH}_{4}} \times\left[\left(\mathrm{MCF}_{\mathrm{ww}} \times \mathrm{BG}_{\mathrm{CH}_{4}}\right)(1-\lambda)\right]
\end{aligned}
$$

The biomass yield $\lambda$ can be determined from the following equation and when the biomass generation rate cannot be assessed, default values for the biomass yield provided in Table 4 and Table 5 can also be used.

$$
\lambda=\frac{\mathrm{Qs} * \mathrm{MLVSSs} * \mathrm{CFs}}{\mathrm{Qww} * \mathrm{OD} * \mathrm{Eff}_{\mathrm{od}} * \mathrm{CFC}}
$$

\subsubsection{Estimation of $\mathrm{CH}_{4}$ and $\mathrm{CO}_{2}$ Emissions from Sludge}

1) When the sludge is digested on-site, then there will be additional $\mathrm{CO}_{2}$ and $\mathrm{CH}_{4}$ and this is applicable for all sludge digesters. The estimation of GHG can be done by the following equations, when:

a) The sludge digester is the only biological treatment process at the facility.

b) Additional waste streams are fed to the sludge digester.

c) Other physical/chemical treatment process are conducted on the sludge prior to the digester that alter the mass of carbon entering the digester.

$$
\begin{aligned}
& \mathrm{CO}_{2}=10^{-6} \times \mathrm{Qs} \times \mathrm{MLVSS} \times \mathrm{CFs} \times\left(\frac{44}{12}\right) \times\left(1-\mathrm{MCFs} \times \mathrm{BG}_{\mathrm{CH}_{4}}\right) \\
& \mathrm{CH}_{4}=10^{-6} \times \mathrm{Qs} \times \mathrm{MLVSS} \times \mathrm{CFs} \times\left(\frac{16}{12}\right) \times\left(1-\mathrm{MCFs} \times \mathrm{BG}_{\mathrm{CH}_{4}}\right)
\end{aligned}
$$

2) For most sludge digesters, the only solids entering the unit are those generated in the wastewater treatment system and for these cases, the following equations can be used to determine the sludge digester's emissions based on the feed to the wastewater treatment process.

$$
\mathrm{CO}_{2}=10^{-6} \times \mathrm{Qww} \times \mathrm{OD} \times \mathrm{Eff}_{\mathrm{OD}} \times \mathrm{CF}_{\mathrm{CO}_{2}} \times\left[\lambda\left(1-\mathrm{MCFs} \times \mathrm{BG}_{\mathrm{CH}_{4}}\right)\right]
$$




$$
\mathrm{CH}_{4}=10^{-6} \times \mathrm{Qww} \times \mathrm{OD} \times \mathrm{Eff}_{\mathrm{OD}} \times \mathrm{CF}_{\mathrm{CH}_{4}} \times\left[\lambda\left(\mathrm{MCFs} \times \mathrm{BG}_{\mathrm{CH}_{4}}\right)\right]
$$

where,

$\mathrm{CO}_{2}=\mathrm{CO}_{2}$ emission rate $(\mathrm{Mg} \mathrm{CO} / \mathrm{hr})$;

$\mathrm{CH}_{4}=\mathrm{CH}_{4}$ emission rate $(\mathrm{Mg} \mathrm{CH} / \mathrm{hr})$;

Qww $=$ Wastewater influent flow rate $\left(\mathrm{m}^{3} / \mathrm{hr}\right)$;

$\mathrm{OD}=$ Oxygen demand of influent wastewater to the biological treatment unit determined as either; $\mathrm{BOD}_{5}$ or $\mathrm{COD}\left(\mathrm{mg} / \mathrm{L}=\mathrm{g} / \mathrm{m}^{3}\right)$;

Eff $_{\mathrm{OD}}=$ Oxygen demand removal efficiency of the biological treatment unit;

$\mathrm{CF}_{\mathrm{CO}_{2}}=$ Conversion factor for maximum $\mathrm{CO}_{2}$ generation per unit of oxygen demand;

$\mathrm{CF}_{\mathrm{CH}_{4}}=$ Conversion factor for maximum $\mathrm{CH}_{4}$ generation per unit of oxygen demand;

$\mathrm{MCF}_{\mathrm{WW}}=$ methane correction factor for wastewater treatment unit;

$\mathrm{BG}_{\mathrm{CH}_{4}}=$ Fraction of carbon as $\mathrm{CH}_{4}$ in generated biogas (default is 0.65);

$\mathrm{Qs}=$ Waste sludge stream flow rate $\left(\mathrm{m}^{3} / \mathrm{hr}\right)$;

$\mathrm{Qww}=$ Wastewater influent flow rate $\left(\mathrm{m}^{3} / \mathrm{hr}\right)$;

MLVSSs = Mixed liquor volatile suspended solids concentration of the waste sludge stream $(\mathrm{mg} / \mathrm{L})$;

$\lambda=$ Biomass yield ( $\mathrm{g}$ C converted to biomass/g $\mathrm{C}$ consumed in the wastewater treatment process).

\subsubsection{Estimation of $\mathrm{N}_{2} \mathrm{O}$ Emissions}

The amount of nitrogen present in the influent wastewater will determine the $\mathrm{N}_{2} \mathrm{O}$ generation potential. The treatment process will also affect the magnitude of the $\mathrm{N}_{2} \mathrm{O}$ emissions. $\mathrm{N}_{2} \mathrm{O}$ emissions for both aerobic and anaerobic processes using an average value for the percent of influent TKN emitted as $\mathrm{N}_{2} \mathrm{O}$.

Table 4. Default values for methane correction factor (MCF) and biomass yield $(\lambda)$.

\begin{tabular}{lcc}
\hline \multicolumn{1}{c}{ Treatment system } & MCF & $\lambda$ \\
\hline Wastewater treatment processes & & \\
Aerated treatment process (activated sludge system), & 0 & 0.65 \\
well managed & 0.3 & 0.45 \\
Aerated treatment process, overloaded (anoxic areas) & 0.8 & 0.1 \\
Anaerobic treatment process (anaerobic reactor) & 0.2 & 0 \\
Facultative lagoon, shallow (<2 m deep) & 0.8 & $\lambda$ \\
Facultative lagoon, shallow ( $>2$ m deep) & & $\lambda$ \\
Sludge treatment & 0 & from wastewater \\
Aerobic sludge digestion & 0.8 & \\
Anaerobic sudge digestion & & 0.8 \\
\hline
\end{tabular}

Source: IPCC (2006). 
Table 5. Correction factors for different measurement method.

\begin{tabular}{ccc}
\hline Correction factor term & \multicolumn{2}{c}{$\begin{array}{c}\text { Correction factor }(\mathrm{CF}) \text { for designated } \\
\text { measurement method }\end{array}$} \\
\hline & BOD5 or COD & TOC as methane \\
\hline $\mathrm{CF}_{\mathrm{CO}_{2}}$ & 1.375 & 3.667 \\
$\mathrm{CF}_{\mathrm{CH}_{4}}$ & 0.5 & 1.333 \\
$\mathrm{CFs}$ & 0.53 & 0.53 \\
$\mathrm{CFc}$ & 0.375 & 1 \\
\hline
\end{tabular}

Source: IPCC (2006).

$$
\mathrm{N}_{2} \mathrm{O}_{\text {wwtp }}=\mathrm{Q}_{\mathrm{i}} \times \mathrm{TKN} \times \mathrm{EF}_{\mathrm{N}_{2} \mathrm{O}} \times\left(\frac{44}{28}\right) \times 10^{-6}
$$

where,

$$
\begin{aligned}
& \mathrm{N}_{2} \mathrm{O}_{\text {WwTP }}=\mathrm{N}_{2} \mathrm{O} \text { emissions generated from WWTP process }\left(\mathrm{Mg} \mathrm{N}_{2} \mathrm{O} / \mathrm{hr}\right) ; \\
& \mathrm{Q}_{\mathrm{i}}=\text { Wastewater influent flow rate }\left(\mathrm{m}^{3} / \mathrm{hr}\right) ; \\
& \mathrm{TKN}_{\mathrm{i}}=\text { Amount of TKN in the influent }\left(\mathrm{mg} / \mathrm{L}=\mathrm{g} / \mathrm{m}^{3}\right) ; \\
& \mathrm{EF}_{\mathrm{N}_{2} \mathrm{O}}=\mathrm{N}_{2} \mathrm{O} \text { emission factor }\left(\mathrm{g} \mathrm{N} \text { emitted as } \mathrm{N}_{2} \mathrm{O} \text { per } \mathrm{g} \mathrm{TKN}\right. \text { in influent), } \\
& =0.0050 \mathrm{~g} \mathrm{~N} \text { emitted as } \mathrm{N}_{2} \mathrm{O} / \mathrm{g} \mathrm{TKN}[22] .
\end{aligned}
$$

Source: Research Triangle Institute report to USEPA.

\subsection{Emissions of GHG from Industries}

In respect of emissions of an industrial plant there Scopes have been defined by the United Nations. As per the GHG Protocol Initiative 2004, the Scope 1 is the direct GHG emissions which includes GHG emissions that occur from the own sources of the company. The Scope 2 includes the emissions that occur from the use of electricity and the generation of purchased electricity bought and consumed and the emissions from Scope 1. Due to the use of electricity of the plant the emissions during the production of electricity are to be included to the emissions of the plant. Scope 3 includes the emissions from Scopes 1 and 2 and the emissions that occur during the production of the chemicals that are used in the pants [8].

To estimate the GHG emissions of the wastewater treatment plants (WWTP) in a comparable way the considered emissions have to be listed. The selected boundaries are from Scope 3 and are listed below (Bridle Consulting, 2007):

1) $\mathrm{CO}_{2}$ and $\mathrm{N}_{2} \mathrm{O}$ emissions at biotreatment, endogenous respiration, $\mathrm{BOD}$ oxidation nitrification $\mathrm{CO}_{2}$ credit and nitrogen removal;

2) Energy use of plant, for aeration, mixing and pumping which leads to $\mathrm{CO}_{2}$ emissions;

3) Sludge digestion, biogas $\mathrm{CH}_{4}$ and $\mathrm{CO}_{2}$;

4) Sludge disposal, truck emissions trip to reuse/disposal site, $\mathrm{CO}_{2}$ emissions mineralization;

5) Power credit by use of biogas;

6) GHG emissions from chemical use. 


\subsection{Treatment and Discharge Systems and $\mathrm{CH}_{4}$ and $\mathrm{N}_{2} \mathrm{O}$ Generation Potential}

The treatment systems that provide anaerobic environments will generally produce $\mathrm{CH}_{4}$ whereas systems that provide aerobic environments will normally produce little or no $\mathrm{CH}_{4}$ [1]. In lagoons without mixing or aeration, their depth is a critical factor in $\mathrm{CH}_{4}$ production. Shallow lagoons, less than 1 meter in depth, generally provide aerobic conditions and little or no $\mathrm{CH}_{4}$ is likely to be produced. Lagoons deeper than about 2 - 3 meters will generally provide anaerobic environments and significant $\mathrm{CH}_{4}$ production can be expected.

\section{Maximum $\mathrm{CH}_{4}$ Producing Capacity for Domestic Wastewater}

The potential of $\mathrm{CH}_{4}$ that could be generated from the domestic wastewater can be determined based on BOD or COD as recommended by the Intergovernmental Panel on Climate Change (IPCC). The annual methane emissions from domestic wastewater can be expressed as (IPCC, 2002): [1].

$$
\mathrm{CH}_{4} \text { Emissions }=\left\{\sum_{\mathrm{i}}^{\mathrm{j}}(\mathrm{Ui} * \mathrm{Tij} * \mathrm{EFj})\right\}(\mathrm{TOW}-\mathrm{S})-\mathrm{R}
$$

where:

$\mathrm{CH}_{4}$ Emissions $=\mathrm{CH}_{4}$ emissions in inventory year, $\mathrm{kg} \mathrm{CH}_{4} / \mathrm{yr}$;

TOW $=$ total organics in wastewater in inventory year, $\mathrm{kg} \mathrm{BOD} / \mathrm{yr}$;

$\mathrm{S}=$ organic component removed as sludge in inventory year, $\mathrm{kg} \mathrm{BOD} / \mathrm{yr}$;

$\mathrm{Ui}=$ fraction of population in income group $\mathrm{i}$ in inventory year;

$\mathrm{Ti}, \mathrm{j}=$ degree of utilization of treatment/discharge pathway or system, $\mathrm{j}$, for each income group fractioning inventory year;

$\mathrm{i}=$ income group: rural, urban high income and urban low income;

$\mathrm{j}=$ each treatment/discharge pathway or system;

$\mathrm{EFj}=$ emission factor, $\mathrm{kg} \mathrm{CH}_{4} / \mathrm{kg}$ BOD;

$\mathrm{R}=$ amount of $\mathrm{CH}_{4}$ recovered in inventory year, $\mathrm{kg} \mathrm{CH}_{4} / \mathrm{yr}$.

The emission factor is a function of the maximum $\mathrm{CH}_{4}$ producing potential (Bo) and the methane correction factor (MCF).

$$
\mathrm{EFi}=\mathrm{Bo} \times \mathrm{MCFi} \text {, }
$$

where,

$\mathrm{EFj}=$ emission factor, $\mathrm{kg} \mathrm{CH}_{4} / \mathrm{kg}$ BOD;

$\mathrm{j}=$ each treatment/discharge pathway or system;

$\mathrm{Bo}=$ maximum $\mathrm{CH}_{4}$ producing capacity, $\mathrm{kg} \mathrm{CH}_{4} / \mathrm{kg} \mathrm{BOD}$;

$\mathrm{MCFj}=$ methane correction factor (fraction).

Generally, the country specific data may be used to determine the emission factor. In the case of non-availability of country specific data, default values may also be used. Accordingly, default maximum $\mathrm{CH}_{4}$ producing capacity for domestic wastewater can be determined [23].

The maximum $\mathrm{CH}_{4}$ producing capacity for domestic wastewater

$=0.60 \mathrm{~kg} \mathrm{CH}_{4} / \mathrm{kg} \mathrm{BOD;}$

$=0.25 \mathrm{~kg} \mathrm{CH}_{4} / \mathrm{kg} \mathrm{COD}$. 


\subsection{Control Measures for Reduction of GHG}

\subsubsection{GHG Emissions and Reduction Strategies}

In order to control the emission of GHG in domestic wastewater the $\mathrm{CH}_{4}$ may be recycled and reused during the process. In anaerobic treatment system, the $\mathrm{CH}_{4}$ may be recycled to replace the wastewater or sludge oxidation treatment system. The COD discharge is the oxygen required for the chemical oxidant to oxidize the organic pollutants in the water. Generally the amount of $\mathrm{CH}_{4}$ generated from treated wastewater with high COD or BOD concentration is more than that generated from that with lower concentrations. $\mathrm{COD} / \mathrm{N}$ ratio in the reactor seems to have an effect on $\mathrm{N}_{2} \mathrm{O}$ emission. During denitrification, in the activated sludge process a relatively low $\mathrm{COD} / \mathrm{N}$ ratio is the main parameter leading to $\mathrm{N}_{2} \mathrm{O}$ production. The $\mathrm{N}_{2} \mathrm{O}$ increase with the decrease of $\mathrm{NH}_{3}$ and thus during aerobic digestion the nitrification plays an important role in $\mathrm{N}_{2} \mathrm{O}$ emissions [24].

Research with the objective of reducing the GHGs emissions in the wastewater and waste treatment and disposal field was a hot topic in line with the commencement of Kyoto Protocol in 2008 until 2012. The reduced GHGs emission either from the wastewater treatment process improvement or effluent and biomass recycling will generate Certified Emission Reduction (CER) for sale or export. Generally, measurements intended to reduce GHGs emissions in the wastewater treatment section could be achieved through the following aspects.

\subsubsection{Proper Wastewater Treatment}

The emission of GHG depends on the selection of wastewater treatment process based on the wastewater composition, organic loading rate, and the anticipated effluent quality. Normally anaerobic wastewater treatment processes are preferred as they could reduce GHGs emission by energy recycling in the form of $\mathrm{CH}_{4}$. A study showed that the anaerobic wastewater treatments are applicable when level of the biochemical oxygen demand (BOD) concentrations of the wastewater is more than $300 \mathrm{mg} / \mathrm{L}$ [25] [26]. In a particular situation, various anaerobic treatment processes have different GHGs reduction potential. During the treatment of low strength wastewater the $\mathrm{CH}_{4}$ may be dissolved in the effluent leading to significant loss of $\mathrm{CH}_{4}$. The $\mathrm{CO}_{2}$ and $\mathrm{CH}_{4}$ generated due to improper wastewater treatment reduced the possibility of carbon sequestration and energy recovery [27] [28] and the GHG emissions can be reduced by the regulation and control of process and operational parameters such as oxidation reduction potential, $\mathrm{DO}$ and $\mathrm{COD} / \mathrm{N}$ ratio.

\subsubsection{Control of Wastewater Treatment Plants}

Performance of control strategies with adjusted flow of different combinations of $Q W$ values can enable a reduction of GHG emissions. The predominant source of reduction in operating costs is the reduction of sludge produced for disposal, not reduction in pumping costs. The energy cost actually increase due to increased aeration requirements to maintain the desired level. But the reduction of GHG emissions due to the reduction in energy required for pumping is negligible. A high SRT increases direct non- $\mathrm{N}_{2} \mathrm{O}$ emissions from the bioreactor 
and indirect emissions resulting from electricity use [16].

DO control strategy offers superior performance with regard to GHG emissions, operational costs and effluent quality. Increasing the SRT, can result in reduction of emission and cost but direct non- $\mathrm{N}_{2} \mathrm{O}$ emissions are increased. Developing control strategies to provide the greatest possible energy recovery may not always be preferable with regard to reducing GHG emissions and operational costs, since the effects of reduced energy recovery can be offset by the reduction in cost and emissions associated with sludge disposal, and a greater effluent quality may be achieved.

\subsubsection{Recycling of Treated Wastewater and Excess Sludge}

The reduction in the total emission of $\mathrm{CH}_{4}$ could be achieved by the biogas reuse. The $\mathrm{CH}_{4}$ can also be used as a source of renewable energy for the generation of electricity. It may be utilized as raw material to produce organic acids or biodegradable plastic. Further the aerobically treated sludge could be used as manure or organic fertilizer and for soil reclamation.

\subsubsection{Systematic Strategies for the Future Wastewater Treatment}

The cost-effective and energy-saving technology with low solid waste and GHGs emission shall be preferred. The excess sludge is rich in carbon, nitrogen and phosphorus, and micronutrients which could be used as raw material for industrial production. The excess sludge could be reduced for further treatment by recycling, for reducing the emission of GHG and for cost reduction. The goal intended to reduce the GHGs emissions from wastewater and excess sludge disposal could be achieved through the proper treatment of wastewater, choices for rational wastewater treatment process and recycling of treated wastewater and excess sludge.

\subsection{Sample Collection and Testing}

The samples of both the influent and effluent were collected at regular interval and were tested as per the standard testing methods. The physiochemical and biological parameters like $\mathrm{pH}$, temperature, TDS, TSS, $\mathrm{BOD}, \mathrm{COD}, \mathrm{N}$ as $\mathrm{NO}_{3}$ and $\mathrm{P}$ as $\mathrm{PO}_{4}$ were tested for both the influent and effluent. However in this study the average values of the influent and effluent BOD from the SBR, oxidation pond and UASB were adopted for the estimation of the emissions of GHG. Similarly, samples were collected from the SBR and tested for the BOD, MLVSS, TKN and other parameters to study the variation of the biomass yield coefficient in the estimation of GHG emissions.

\section{Results and Discussion}

In this study, the emissions of GHG in Puducherry from the oxidation ponds of 12.5 Mld, UASB of 2.5 Mld (2 Nos) and one SBR of 17 Mld were determined. Only the on-site sources for the emissions were considered in this study. The emissions of GHGs in wastewater and sludge in SBR, UASB and Oxidation ponds in Puducherry were determined based on the IPCC guidelines. 


\section{Estimation of $\mathrm{CO}_{2}, \mathrm{CH}_{4}$ and $\mathrm{N}_{2} \mathrm{O}$ from the SBR, UASB and Oxidation Ponds}

The estimation of $\mathrm{CO}_{2}$ in the aerobic treatment of wastewater in SBR was calculated using the Equation (3.1). There is no emission of $\mathrm{CH}_{4}$ during aerobic process. The emissions of $\mathrm{CO}_{2}$ and $\mathrm{CH}_{4}$ during on site sludge digestion in the sludge drying bed due to the sludge digester's emissions based on the feed to the wastewater treatment process by using the Equations (3.6) and (3.7) and the same is designated as SBR (A1). Similarly the emissions of $\mathrm{CO}_{2}$ and $\mathrm{CH}_{4}$ during on site sludge digestion were calculated based on the MLVSS and the volume of the sludge wasted by considering the Equations (3.4) and (3.5), since chemical treatment process are carried out on the sludge prior to the digester that alter the mass of carbon entering the digester and the same is designated as SBR (A2). The emission of $\mathrm{N}_{2} \mathrm{O}$ from the sludge digestion was also calculated using the Equation (3.8).

The emissions of $\mathrm{CO}_{2}$ and $\mathrm{CH}_{4}$ during the anaerobic treatment of wastewater in the UASB and additional emissions of $\mathrm{CO}_{2}$ and $\mathrm{CH}_{4}$ during on site sludge digestion in the sludge drying bed were calculated. In the case of oxidation ponds the emissions of $\mathrm{CO}_{2}$ and $\mathrm{CH}_{4}$ from the aerobic zone and the additional emissions of $\mathrm{CO}_{2}, \mathrm{CH}_{4}$ and $\mathrm{N}_{2} \mathrm{O}$ from the sludge digestion in the anaerobic zone were calculated and the details of estimation of $\mathrm{CO}_{2}, \mathrm{CH}_{4}$ and $\mathrm{N}_{2} \mathrm{O}$. The estimation of GHG in UASB, Oxidation Ponds and SBR (A1) are shown in Table 6.

The emissions of $\mathrm{CO}_{2}$ and $\mathrm{CH}_{4}$ in SBR are influenced by the biomass yield coefficient $\lambda$ and the efficiency of the BOD removal. The biomass yield coefficient is the ratio of the $\mathrm{g} C$ converted to biomass to the $\mathrm{g} C$ consumed in the wastewater treatment process. It is influenced by the volume of the sludge and the mixed liquor volatile suspended solids (MLVSS) concentration of the waste sludge stream $(\mathrm{mg} / \mathrm{L})$. The variation of $\mathrm{CO}_{2}$ emission from the wastewater is shown in Figure 6 and the variation of $\mathrm{CO}_{2}$ from the sludge is shown in Figure 7.

The emissions of $\mathrm{CO}_{2}, \mathrm{CH}_{4}$ and $\mathrm{N}_{2} \mathrm{O}$ for different values of biomass yield coefficient $(\lambda)$ were calculated as given in Table 7 . The variation of biomass yield coefficient and the emissions $\mathrm{CO}_{2}$ from wastewater $\left(\mathrm{CO}_{2}-\mathrm{WW}\right)$ and $\mathrm{CO}_{2}$ ( $\mathrm{CO}_{2}$-Sludge), $\mathrm{CH}_{4}\left(\mathrm{CH}_{4}\right.$-Equ $\left.\mathrm{CO}_{2}\right), \mathrm{N}_{2} \mathrm{O}\left(\mathrm{N}_{2} \mathrm{O}\right.$-Equ $\left.\mathrm{CO}_{2}\right)$ and total equivalent $\mathrm{CO}_{2}$ from sludge in terms of equivalent $\mathrm{CO}_{2}$ are shown in Figure 8. It may be seen that as the biomass yield coefficient increases the emission of $\mathrm{CO}_{2}$ from wastewater decreases. But the total equivalent $\mathrm{CO}_{2}, \mathrm{CO}_{2}$ from sludge, $\mathrm{CH}_{4}-\mathrm{Equ} \mathrm{CO}_{2}$, and $\mathrm{N}_{2} \mathrm{O}$-Equ $\mathrm{CO}_{2}$ increase as the biomass yield coefficient increases.

The total emissions of $\mathrm{CO}_{2}$ and equivalent $\mathrm{CO}_{2}$ of $\mathrm{CH}_{4}$ and $\mathrm{N}_{2} \mathrm{O}$ for the biomass yield coefficients of 0.1 to 0.65 are shown in Figure 9.

The emissions of $\mathrm{CO}_{2}, \mathrm{CH}_{4}$ and $\mathrm{N}_{2} \mathrm{O}$ from various treatment plants and the equivalent $\mathrm{CO}_{2}$ of GHG and the total equivalent $\mathrm{CO}_{2}$ are shown in Table 8. The total emissions of equivalent $\mathrm{CO}_{2}$ from the UASB and Oxidation ponds are 9532 tons per year, whereas the total emissions of equivalent $\mathrm{CO}_{2}$ from the SBR is 7649 tons per year, which is only $80 \%$ of the total $\mathrm{CO}_{2}$ emissions. However, 
Table 6. Estimation of $\mathrm{CO}_{2}, \mathrm{CH}_{4}$ and $\mathrm{N}_{2} \mathrm{O}$ from UASB, oxidation ponds and SBR.

\begin{tabular}{|c|c|c|c|c|c|c|c|c|c|c|}
\hline & \multirow[t]{2}{*}{ Emission of greenhouse gases from wastewater and sludge } & \multicolumn{3}{|c|}{ UASB 2.5 MLD } & \multicolumn{3}{|c|}{$\begin{array}{l}\text { Oxidation ponds } 12.5 \\
\text { MLD }\end{array}$} & \multicolumn{3}{|c|}{ SBR 17 MLD (A1) } \\
\hline & & $\mathrm{CO}_{2}$ & $\mathrm{CH}_{4}$ & $\mathrm{~N}_{2} \mathrm{O}$ & $\mathrm{CO}_{2}$ & $\mathrm{CH}_{4}$ & $\mathrm{~N}_{2} \mathrm{O}$ & $\mathrm{CO}_{2}$ & $\mathrm{CH}_{4}$ & $\mathrm{~N}_{2} \mathrm{O}$ \\
\hline & Emission of $\mathrm{CO}_{2} \& \mathrm{CH}_{4} \&$ from wastewater & $\begin{array}{l}\mathrm{Mg} / \\
\text { day }\end{array}$ & $\begin{array}{l}\mathrm{Mg} / \\
\text { day }\end{array}$ & $\begin{array}{l}\mathrm{Mg} / \\
\text { day }\end{array}$ & $\begin{array}{l}\mathrm{Mg} / \\
\text { day }\end{array}$ & $\begin{array}{l}\mathrm{Mg} / \\
\text { day }\end{array}$ & $\begin{array}{l}\mathrm{Mg} / \\
\text { day }\end{array}$ & $\begin{array}{l}\mathrm{Mg} / \\
\text { day }\end{array}$ & $\begin{array}{l}\mathrm{Mg} / \\
\text { day }\end{array}$ & $\begin{array}{l}\mathrm{Mg} / \\
\text { day }\end{array}$ \\
\hline 3.1 & $\begin{aligned} \mathrm{CO}_{2}= & 10^{-6} \times \mathrm{QWW} \times \mathrm{OD} \times \mathrm{Eff}_{\mathrm{OD}} \times \mathrm{CF}_{\mathrm{CO}_{2}} \\
& \times\left[\left(1-\mathrm{MCF}_{\mathrm{ww}} \times \mathrm{BG}_{\mathrm{CH}_{4}}\right)(1-\lambda)\right]\end{aligned}$ & 0.01300 & & & 0.1122 & & & 0.092 & & \\
\hline 3.2 & $\begin{aligned} \mathrm{CH}_{4}= & 10^{-6} \times \mathrm{QwW} \times \mathrm{OD} \times \mathrm{Eff}_{\mathrm{OD}} \times \mathrm{CF}_{\mathrm{CH}_{4}} \\
& \times\left[\left(\mathrm{MCF}_{\mathrm{ww}} \times \mathrm{BG}_{\mathrm{CH}_{4}}\right)(1-\lambda)\right]\end{aligned}$ & & 0.0051 & & & 0.0061 & & & 0.00 & \\
\hline \multirow[t]{2}{*}{3.3} & $\lambda=(\mathrm{Qs} \times \mathrm{MLVSSs} \times \mathrm{CFs}) /\left(\mathrm{Qww} \times \mathrm{OD} \times \mathrm{Eff}_{\mathrm{od}} \times \mathrm{CFc}\right)$ & & & & & & & & & \\
\hline & Emission of $\mathrm{CO}_{2} \& \mathrm{CH}_{4} \&$ from sludge & & & & & & & & & \\
\hline 3.4 & $\mathrm{CO}_{2}=10^{-6} \times \mathrm{Qs} \times \mathrm{MLVSS} \times \mathrm{CFs} \times(44 / 12) \times\left(1-\mathrm{MCFs} \times \mathrm{BG}_{\mathrm{CH}_{4}}\right)$ & & & & & & & & & \\
\hline 3.5 & $\mathrm{CH}_{4}=10^{-6} \times \mathrm{Qs} \times \mathrm{MLVSS} \times \mathrm{CFs} \times(16 / 12) \times\left(1-\mathrm{MCFs} \times \mathrm{BG}_{\mathrm{CH}_{4}}\right)$ & & & & & & & & & \\
\hline 3.6 & $\mathrm{CO}_{2}=10^{-6} \times \mathrm{QWW} \times \mathrm{OD} \times \mathrm{Eff}_{\mathrm{OD}} \times \mathrm{CF}_{\mathrm{CO}_{2}} \times\left[\lambda\left(1-\mathrm{MCFs} \times \mathrm{BG}_{\mathrm{CH}_{4}}\right)\right]$ & 0.0074 & & & 0.0371 & & & 0.0729 & & \\
\hline 3.7 & $\mathrm{CH}_{4}=10^{-6} \times \mathrm{QwW} \times \mathrm{OD} \times \mathrm{Eff}_{\mathrm{OD}} \times \mathrm{CF}_{\mathrm{CH}_{4}} \times\left[\lambda\left(\mathrm{MCFs} \times \mathrm{BG}_{\mathrm{CH}_{4}}\right)\right]$ & & 0.0029 & & & 0.0146 & & & 0.0287 & \\
\hline \multirow[t]{7}{*}{3.8} & $\mathrm{~N}_{2} \mathrm{O}_{\mathrm{wwp}}=10^{-6} \times \mathrm{QwW} \times \mathrm{TKN} \times \mathrm{EF}_{\mathrm{N}_{2} \mathrm{O}} \times(44 / 28)$ & & & 0.00001 & & & 0.00006 & & & 0.00008 \\
\hline & CHG Mg per Hr & 0.0204 & 0.0080 & 0.00001 & 0.1493 & 0.0207 & 0.00006 & 0.1649 & 0.0287 & 0.00008 \\
\hline & Equivalent $\mathrm{CO}_{2} \mathrm{Mg}$ per $\mathrm{Hr}$ & 0.0204 & 0.1686 & 0.0038 & 0.1493 & 0.4352 & 0.0190 & 0.1649 & 0.6030 & 0.0259 \\
\hline & Total equivalent $\mathrm{CO}_{2} \mathrm{Mg} /$ day & & & 4.628 & & & 14.486 & & & 19.051 \\
\hline & Total equivalent $\mathrm{CO}_{2}$ Tonnes per year (Tpy) & & & 1858 & & & 5816 & & & 7649 \\
\hline & Equivalent $\mathrm{CO}_{2}$ per kg BOD & & & 6.17 & & & 3.86 & & & 3.74 \\
\hline & Equivalent $\mathrm{CO}_{2}$ per MLD Mg/MLD & & & 1.85 & & & 1.16 & & & 1.12 \\
\hline
\end{tabular}

Table 7. Emissions of GHG for various biomass yield coefficient.

\begin{tabular}{cccccccccc}
\hline & \multicolumn{7}{c}{ Biomass yield coefficient $(\lambda)$} \\
\cline { 2 - 9 } GHG emissions $\mathrm{Mg} / \mathrm{hr}$ & $\mathbf{0}$ & $\mathbf{0 . 1}$ & $\mathbf{0 . 2}$ & $\mathbf{0 . 3}$ & $\mathbf{0 . 4}$ & $\mathbf{0 . 5}$ & $\mathbf{0 . 6}$ & $\mathbf{0 . 6 5}$ \\
\hline $\mathrm{CO}_{2}$-wastewater & 0.0814 & 0.0733 & 0.0652 & 0.0570 & 0.0489 & 0.0407 & 0.0326 & 0.0285 \\
$\mathrm{CO}_{2}$-sludge & 0.0000 & 0.0081 & 0.0163 & 0.0244 & 0.0326 & 0.0407 & 0.0489 & 0.0529 \\
$\mathrm{CH}_{4}$-equivalent $\mathrm{CO}_{2}$ & 0.0000 & 0.0323 & 0.0647 & 0.0970 & 0.1294 & 0.1617 & 0.1940 & 0.2102 \\
$\mathrm{~N}_{2} \mathrm{O}$ equivalent $\mathrm{CO}_{2}$ & 0.0133 & 0.0133 & 0.0133 & 0.0133 & 0.0133 & 0.0133 & 0.0133 & 0.0133 \\
Total equivalent $\mathrm{CO}_{2}$ & 0.0947 & 0.1271 & 0.1594 & 0.1918 & 0.2241 & 0.2564 & 0.2888 & 0.3050 \\
\hline
\end{tabular}

further study in the determination of $\mathrm{CO}_{2}$ emissions showed that when other physical/chemical treatment process are conducted on the sludge prior to the digester, the emissions of $\mathrm{CO}_{2}$ could be reduced to 5793 tons per year, which is only $60 \%$ of the total equivalent $\mathrm{CO}_{2}$ emissions. The emissions of equivalent $\mathrm{CO}_{2}$ per unit of organic load i.e., per kg of BOD for each plant were also compared. The equivalent emissions of $\mathrm{CO}_{2}$ per for the SBR were $2.83 \mathrm{~kg}$ per $\mathrm{kg}$ of BOD, whereas the $\mathrm{CO}_{2}$ emissions for the UASB and oxidation ponds were 6.17 and $3.86 \mathrm{~kg}$ per $\mathrm{kg}$ of $\mathrm{BOD}$ respectively. From these, it can be seen that the 


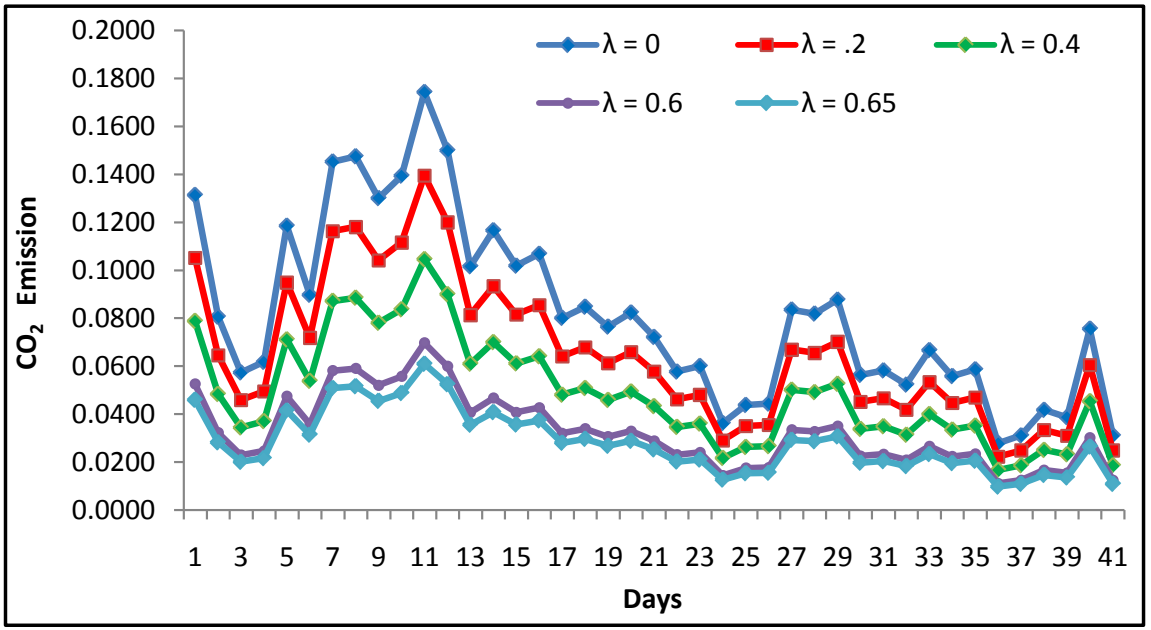

Figure 6. Variation of $\mathrm{CO}_{2}$ emission $(\mathrm{Mg} / \mathrm{Hr})$ from wastewater in SBR.

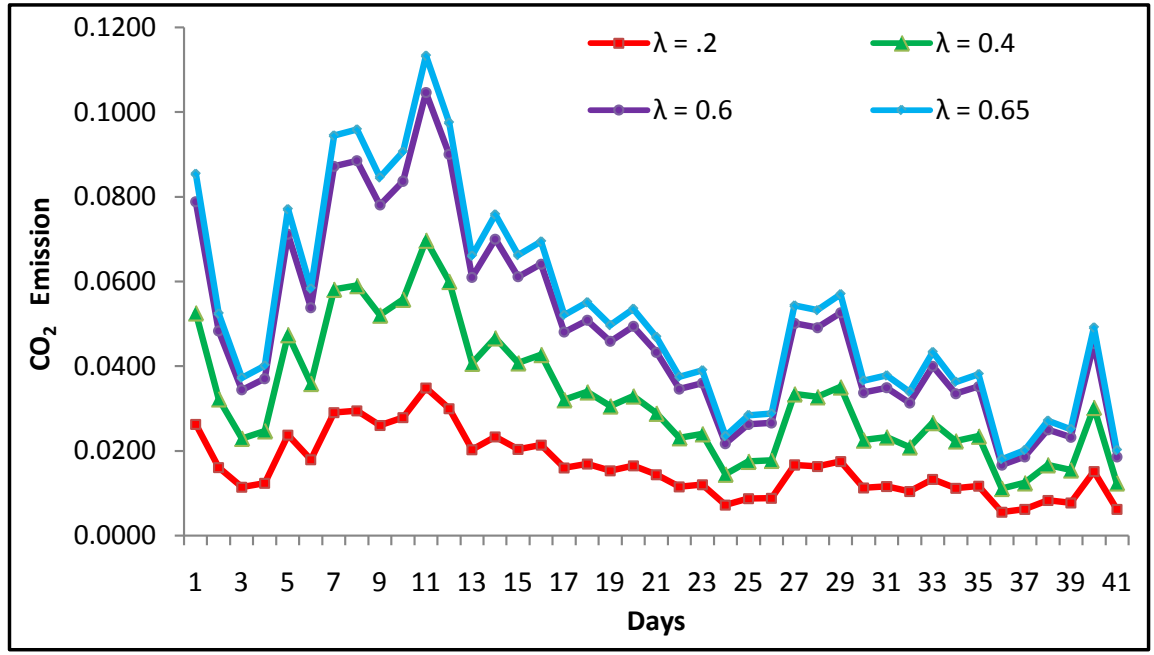

Figure 7. Variation of $\mathrm{CO}_{2}$ emission $(\mathrm{Mg} / \mathrm{Hr})$ from sludge in SBR.

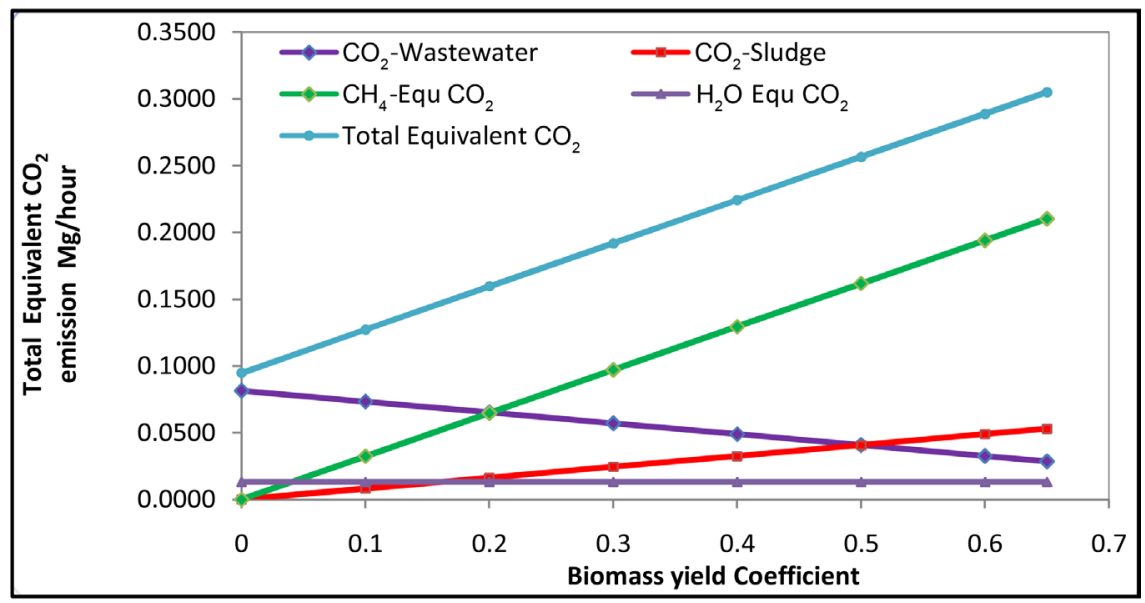

Figure 8. Emission of GHG (Mg/Hr) vs. biomass yield $(\lambda)$.

performance of the SBR is better than the performance of the UASB and oxidation ponds in the emission of GHG. 


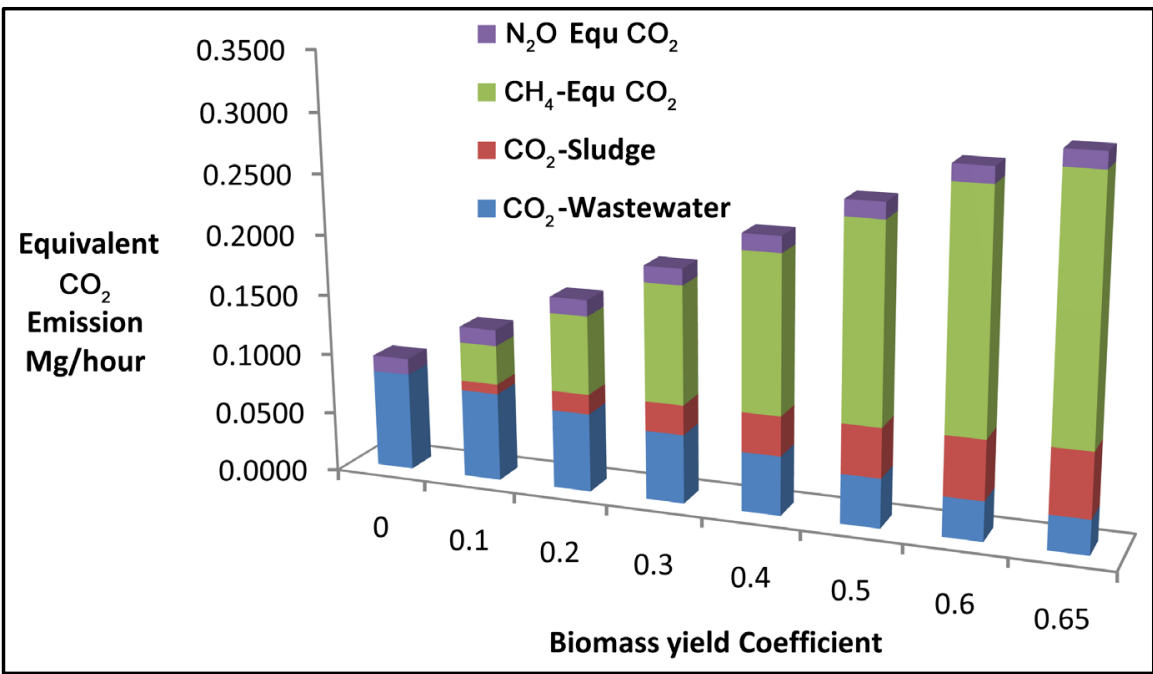

Figure 9. Total emission of GHG-equivalent of $\mathrm{kg} \mathrm{CO}_{2}$.

Table 8. Emissions of GHG in UASB, SBR and oxidation ponds.

\begin{tabular}{|c|c|c|c|c|c|c|c|c|c|}
\hline \multirow{2}{*}{$\begin{array}{l}\text { Sewage } \\
\text { treatment } \\
\text { plants }\end{array}$} & \multicolumn{3}{|c|}{$\begin{array}{l}\text { Emission of GHG } \\
\text { (Tons per year) }\end{array}$} & \multicolumn{3}{|c|}{$\begin{array}{l}\text { Emission of } \mathrm{GHG} \\
\text { equivalent } \mathrm{CO}_{2} \\
\text { (Tons per year) }\end{array}$} & \multicolumn{3}{|c|}{ Total equivalent $\mathrm{CO}_{2}$} \\
\hline & $\mathrm{CO}_{2}$ & $\mathrm{CH}_{4}$ & $\mathrm{~N}_{2} \mathrm{O}$ & $\mathrm{CO}_{2}$ & $\mathrm{CH}_{4}$ & $\mathrm{~N}_{2} \mathrm{O}$ & $\begin{array}{l}\text { (Tons per } \\
\text { year) }\end{array}$ & $\begin{array}{l}\text { Mg per } \\
\text { day }\end{array}$ & $\begin{array}{l}\text { per Kg } \\
\text { BOD }\end{array}$ \\
\hline $\begin{array}{c}\text { UASB2.5 MLD } \\
\text { (2 Nos) }\end{array}$ & 196 & 77 & 0.12 & 196 & 1625 & 37 & 3716 & 4.63 & 6.17 \\
\hline $\begin{array}{c}\text { Oxidation ponds } \\
12.5 \mathrm{MLD}\end{array}$ & 1439 & 200 & 0.59 & 1439 & 4194 & 183 & 5816 & 14.49 & 3.86 \\
\hline SBR17 MLD (A1) & 1589 & 277 & 0.80 & 1589 & 5811 & 249 & 7649 & 19.05 & 3.74 \\
\hline SBR 17 MLD (A2) & 1426 & 196 & 0.80 & 1426 & 4118 & 249 & 5793 & 14.42 & 2.83 \\
\hline
\end{tabular}

\section{Conclusion}

The emissions of GHG from the UASB, oxidation ponds and SBR in Puducherry were estimated. The emissions of $\mathrm{CO}_{2}, \mathrm{CH}_{4}$ and $\mathrm{N}_{2} \mathrm{O}$ from all these treatment plants were also estimated based on the guidelines of IPCC and RTI-USEPA and the total equivalent $\mathrm{CO}_{2}$ was computed and analyzed. The impact of biomass yield coefficient on the emissions of GHG was also examined and their variations were also studied. The total emissions of equivalent $\mathrm{CO}_{2}$ from the SBR of $17 \mathrm{Mld}$ capacity are less than $20 \%$ of the total $\mathrm{CO}_{2}$ emissions of $\mathrm{CO}_{2}$ from the UASB and oxidation ponds of $17.5 \mathrm{Mld}$ capacity. Further study revealed that by modifying the treatment process of the sludge from the SBR, by altering the waste sludge flow rate and the MLSS, the total emissions of equivalent $\mathrm{CO}_{2}$, could be reduced and it is possible to achieve a reduction of about $40 \%$ of total equivalent $\mathrm{CO}_{2}$ emissions. The study also established that the emissions of $\mathrm{CO}_{2}$ from the SBR are the least and that the SBR performs well and more efficient in terms of reduction of GHG emissions when compared to that of the UASB and oxidation ponds. 


\section{References}

[1] Doorn, M.R.J., Towprayoon, S., Vieira, S.M.M., Irving, W., Palmer, C., Pipatti, R. and Wang, C. (2006) Intergovernmental Panel on Climate Change (IPCC) Guidelines for National Greenhouse Gas Inventories.

[2] United States Environmental Protection Agency (USEPA), Research Triangle International (RTI) (2010) Greenhouse Gas Emissions Estimation Methodologies for Biogenic Emissions from Selected Source Categories.

[3] Chai, C., Zhang, D., Yu, Y., Feng, Y. and Wong, M.S. (2015) Carbon Footprint Analyses of Mainstream Wastewater Treatment Technologies under Different Sludge Treatment Scenarios in China. Water, 7, 918-938.

[4] Das, S. (2011) Estimation of Greenhouse Gases Emissions from Biological Wastewater Treatment Plants at Windsor. Electronic Theses and Dissertations, Paper 77.

[5] Trends in Global $\mathrm{CO}_{2}$ Emissions: 2014 Report-The Hague: PBL Netherlands Environmental Assessment Agency. European Commission, Joint Research Centre, Ispra.

[6] Pahuja, N., Pandey, N., Mandal, K. and Bandyopadhyay, C. (2014) GHG Mitigation in India: An Overview of the Current Policy Landscape. Working Paper, World Resources Institute, Washington DC.

http://www.wri.org/publication/ghg-mitigation-ind-policy

[7] MoEF (2010) India Greenhouse Gas Emissions (2007) Report of Ministry of Environment and Forests, Government of India. http://envfor.nic.in/

[8] Snip, L.J.P. (2010) Quantifying the Greenhouse Gas Emissions of Waste Water Treatment Plants. Thesis Project Systems and Control, MES (Environmental Sciences), Wageningen, The Netherlands.

[9] Ma, Z.-Y., Feng, Gao, Q.-X., Lu, Y.-N., Liu, J.-R. and Li, W.-T. (2015) CH4 Emissions and Reduction Potential in Wastewater Treatment in China. Advances in Climate Change Research, 6, 216-224.

[10] U.S. EPA (1983) An Emerging Technology, Sequencing Batch Reactors. A Project Assessment, U.S. Environmental Protection Agency.

[11] Arceivala, S.J. and Asolekakar, S.R. (2008) Wastewater Treatment for Pollution Control and Reuse. Third Edition, Tata McGraw-Hill.

[12] U.S. EPA (1986) Design Manual, Summary Report Sequencing Batch Reactors. EPA/625/8-86/011.

[13] U.S. EPA (1999) Wastewater Technology Fact Sheet Sequencing Batch Reactors. U.S. Environmental Protection Agency, EPA 832-F-99-073.

[14] U.S. EPA (2000) Wastewater Technology Fact Sheet Package Plants. U.S. Environmental Protection Agency, EPA 832-F-00-016.

[15] The New England Interstate Water Pollution Control Commission (2005) Manual for Sequencing Batch Reactor Design and Operational Considerations.

[16] Sweetapple, C., Fu, G. and Butler, D. (2014) Multi-Objective Optimisation of Wastewater Treatment Plant Control to Reduce Greenhouse Gas Emissions. Water Research, 55, 52-62.

[17] Butler, E., Hung, Y.-T., Al Ahmad, M.S., Yeh, R.Y.-L., Liu, R.L.-H. and Fu, Y.-P. (2015) Oxidation Pond for Municipal Wastewater Treatment. Applied Water Science, 7, 31-51.

[18] Hernandez-Paniagua, I.Y., Ramirez-Vargas, R., Ramos-Gomez, M.S., Dendooven, L., Avelar-Gonzalez, F.J. and Thalasso, F. (2014) Greenhouse Gas Emissions from 
Stabilization Ponds in Subtropical Climates. Environmental Technology, 35, 727-734. https://doi.org/10.1080/09593330.2013.848910

[19] Heffernana, B., Blancb, J. and Spanjersc, H. (2012) Evaluation of Greenhouse Gas Emissions from Municipal UASB Sewage Treatment Plants. Journal of Integrative Environmental Sciences, 9, 127-137. https://doi.org/10.1080/1943815X.2012.696546

[20] Guo, J., Ma, F., Qu, Y., Li, A. and Wang, L. (2012) Systematical Strategies for Wastewater Treatment and the Generated Wastes and Greenhouse Gases in China. Frontiers of Environmental Science \& Engineering, 6, 271-279.

[21] Gupta, D. and Singh, S.K. (2015) Energy Use and Greenhouse Gas Emissions from Wastewater Treatment Plants. International Journal of Environmental Engineering, 7, 1-10. https://doi.org/10.1504/IJEE.2015.069251

[22] Chandran, K. (2010) Greenhouse Nitrogen Emission from Wastewater Treatment Operations: Interim Report. Water Environment Research Foundation (WERF), Report No. U4R07a.

[23] Doorn, M.R.J., Strait, R., Barnard, W. and Eklund, B. (1997) Estimate of Global Greenhouse Gas Emissions from Industrial and Domestic Wastewater Treatment. Final Report, EPA-600/R-97-091, Prepared for United States Environmental Protection Agency, Research Triangle Park, NC, USA.

[24] Caniani, D., Esposito, G., Gori, R. and Mannina, G. (2015) Towards a New Decision Support System for Design, Management and Operation of Wastewater Treatment Plants for the Reduction of Greenhouse Gases Emission. Water, 7, 5599-5616.

[25] Cakir, F.Y. and Stenstrom, M.K. (2005) Greenhouse Gas Production: A Comparison between Aerobic and Anaerobic Wastewater Treatment Technology. Water Research, 39, 4197-4203.

[26] Monteith, H.D., Sahely, H.R., MacLean, H.L. and Bagley, D.M. (2005) A Rational Procedure for Estimation of Greenhouse-Gas Emissions from Municipal Wastewater Treatment Plants. Water Environment Research, 77, 390-403. https://doi.org/10.2175/106143005x51978

[27] Préndez, M. and Lara-González, S. (2008) Application of Strategies for Sanitation Management in Wastewater Treatment Plants in Order to Control/Reduce Greenhouse Gas Emission. Journal of Environmental Management, 88, 658-664.

[28] Rosso, D. and Stenstrom, M.K. (2008) The Carbon-Sequestration Potential of Municipal Wastewater Treatment. Chemosphere, 70, 1468-1475. 
Submit or recommend next manuscript to SCIRP and we will provide best service for you:

Accepting pre-submission inquiries through Email, Facebook, LinkedIn, Twitter, etc. A wide selection of journals (inclusive of 9 subjects, more than 200 journals)

Providing 24-hour high-quality service

User-friendly online submission system

Fair and swift peer-review system

Efficient typesetting and proofreading procedure

Display of the result of downloads and visits, as well as the number of cited articles Maximum dissemination of your research work

Submit your manuscript at: http://papersubmission.scirp.org/

Or contact cweee@scirp.org 